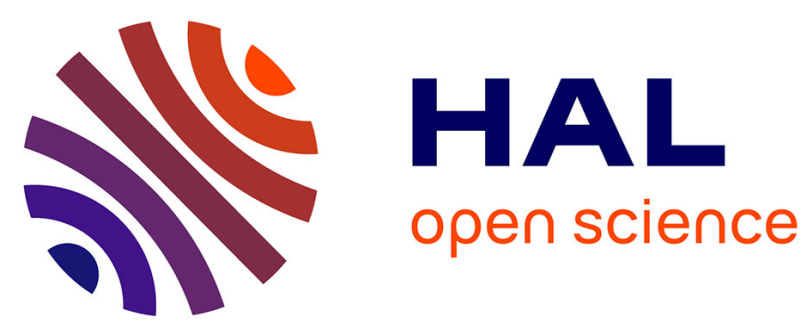

\title{
Petrology, geochemistry, and cosmic-ray exposure age of lherzolitic shergottite Northwest Africa 1950
}

\author{
P. Gillet, Jean-Alix J-A Barrat, P. Beck, B. Marty, R. Greenwood, I.A.
}

Franchi, Marcel Bohn, Joseph Cotten

\section{- To cite this version:}

P. Gillet, Jean-Alix J-A Barrat, P. Beck, B. Marty, R. Greenwood, et al.. Petrology, geochemistry, and cosmic-ray exposure age of lherzolitic shergottite Northwest Africa 1950. Meteoritics and Planetary Science, 2005, 40, pp.1175-1184. 10.1111/j.1945-5100.2005.tb00182.x . hal-00113824

\section{HAL Id: hal-00113824 \\ https://hal.science/hal-00113824}

Submitted on 26 Feb 2013

HAL is a multi-disciplinary open access archive for the deposit and dissemination of scientific research documents, whether they are published or not. The documents may come from teaching and research institutions in France or abroad, or from public or private research centers.
L'archive ouverte pluridisciplinaire HAL, est destinée au dépôt et à la diffusion de documents scientifiques de niveau recherche, publiés ou non, émanant des établissements d'enseignement et de recherche français ou étrangers, des laboratoires publics ou privés. 


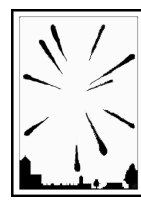

Meteoritics \& Planetary Science 40, Nr 8, 1175-1184 (2005)

Abstract available online at http://meteoritics.org

\title{
Petrology, geochemistry, and cosmic-ray exposure age of lherzolitic shergottite Northwest Africa 1950
}

\author{
P. GILLET ${ }^{1 *}$, J. A. BARRAT ${ }^{2}$, P. BECK ${ }^{1}$, B. MARTY ${ }^{3}$, R. C. GREENWOOD ${ }^{4}$, \\ I. A. FRANCHI ${ }^{4}$, M. BOHN 5 , and J. COTTEN 6 \\ ${ }^{1}$ Laboratoire des Sciences de la Terre, CNRS UMR 5570, Ecole Normale Supérieure de Lyon, 46 Allée d’Italie, 69364 Lyon Cedex 7, France \\ ${ }^{2}$ Domaines Océaniques, CNRS UMR 6538 U.B.O.-I.U.E.M., place Nicolas Copernic, 29280 Plouzané Cedex, France \\ ${ }^{3}$ CRPG-CNRS UPR 2300, 15 rue Notre-Dame des Pauvres, 54501 Vandoeuvre-lès-Nancy Cedex, France \\ ${ }^{4}$ Planetary and Space Science Research Institute, The Open University, Walton Hall, Milton Keynes, MK7 6AA, UK \\ ${ }^{5}$ Ifremer-Centre de Brest, CNRS-UMR 6538, BP70, 29280 Plouzané Cedex, France \\ ${ }^{6}$ Université de Brest, C.N.R.S. UMR 6538, 6 avenue Le Gorgeu, 29100 Brest, France \\ *Corresponding author. E-mail: directeur@ens-lyon.fr
}

(Received 03 March 2005; revision accepted 06 July 2005)

\begin{abstract}
Northwest Africa (NWA) 1950 is a new member of the lherzolitic shergottite clan of the Martian meteorites recently found in the Atlas Mountains. The petrological, mineralogical, and geochemical data are very close to those of the other known lherzolitic shergottites. The meteorite has a cumulate gabbroic texture and its mineralogy consists of olivine $\left(\mathrm{Fo}_{66}\right.$ to $\left.\mathrm{Fo}_{75}\right)$, low and high-Ca pyroxenes $\left(\mathrm{En}_{78} \mathrm{Fs}_{19} \mathrm{Wo}_{2}\right.$ $\left.\mathrm{En}_{60} \mathrm{Fs}_{26} \mathrm{~W}_{14} ; \mathrm{En}_{53} \mathrm{Fs}_{16} \mathrm{Wo}_{31}-\mathrm{En}_{45} \mathrm{Fs}_{14} \mathrm{Wo}_{41}\right)$, and plagioclase $\left(\mathrm{An}_{57} \mathrm{Ab}_{41} \mathrm{Or}_{1}\right.$ to $\mathrm{An}_{40} \mathrm{Ab}_{57} \mathrm{Or}_{3}$; entirely converted into maskelynite during intense shock metamorphism). Accessory minerals include phosphates (merrillite), chromite and spinels, sulfides, and a glass rich in potassium. The oxygen isotopic values lie on the fractional line defined by the other SNC meteorites $\left(\Delta^{17} \mathrm{O}=0.312 \%\right)$. The composition of NWA 1950 is very similar to the other lherzolitic shergottites and suggests an origin from the same magmatic system, or at least crystallization from a close parental melt. Cosmogenic ages indicate an ejection age similar to those of the other lherzolitic shergottites. The intensity of the shock is similar to that observed in other shergottites, as shown by the occurrence of small melt pockets containing glass interwoven with stishovite.
\end{abstract}

\section{INTRODUCTION}

The shergottites, nakhlites, chassignites, and Allan Hills (ALH) 84001 are igneous rocks believed to have formed on Mars (e.g., Treiman et al. 2000). These meteorites show a wide range of petrological characteristics providing clues to deciphering the magmatic processes that have occurred on Mars. Among the shergottite sub-group of the Martian meteorites, the distinction between basaltic, picritic (or olivine-phyric), and lherzolitic shergottites has been made. The first two groups represent the most abundant number of specimens, while only four lherzolitic shergottites have been described so far: ALH A77005 (McSween et al. 1979), Lewis Cliff (LEW) 88516 (Gleason et al. 1997; Harvey et al. 1993), Yamato- (Y-) 793605 (Ikeda, 1997; Mikouchi and Miyamoto, 1996), and Grove Mountains (GRV) 99027 (Hsu et al. 2004). Lherzolitic shergottites, all collected in Antarctica, are interpreted as olivine and pyroxene cumulates possibly formed at depth, while picritic and basaltic shergottites are interpreted as surface (or subsurface) magmatic products. We report in this paper a petrological, mineralogical, and geochemical description of Northwest Africa 1950 (NWA 1950), a new lherzolitic shergottite found in the Atlas Mountains (Morocco). Two stones weighing 414 and 398 grams were recovered. The characteristics of this new meteorite will be compared with those of other related meteorites.

\section{CHARACTERIZATION TECHNIQUES}

We made petrographic observations and quantitative chemical analyses of the various mineralogical phases on a polished section. We took backscattered electron (BSE) images with a JEOL JSM6301-F scanning electron microscope and measured major and minor chemical element abundances using a CAMECA SX50 electron microprobe 


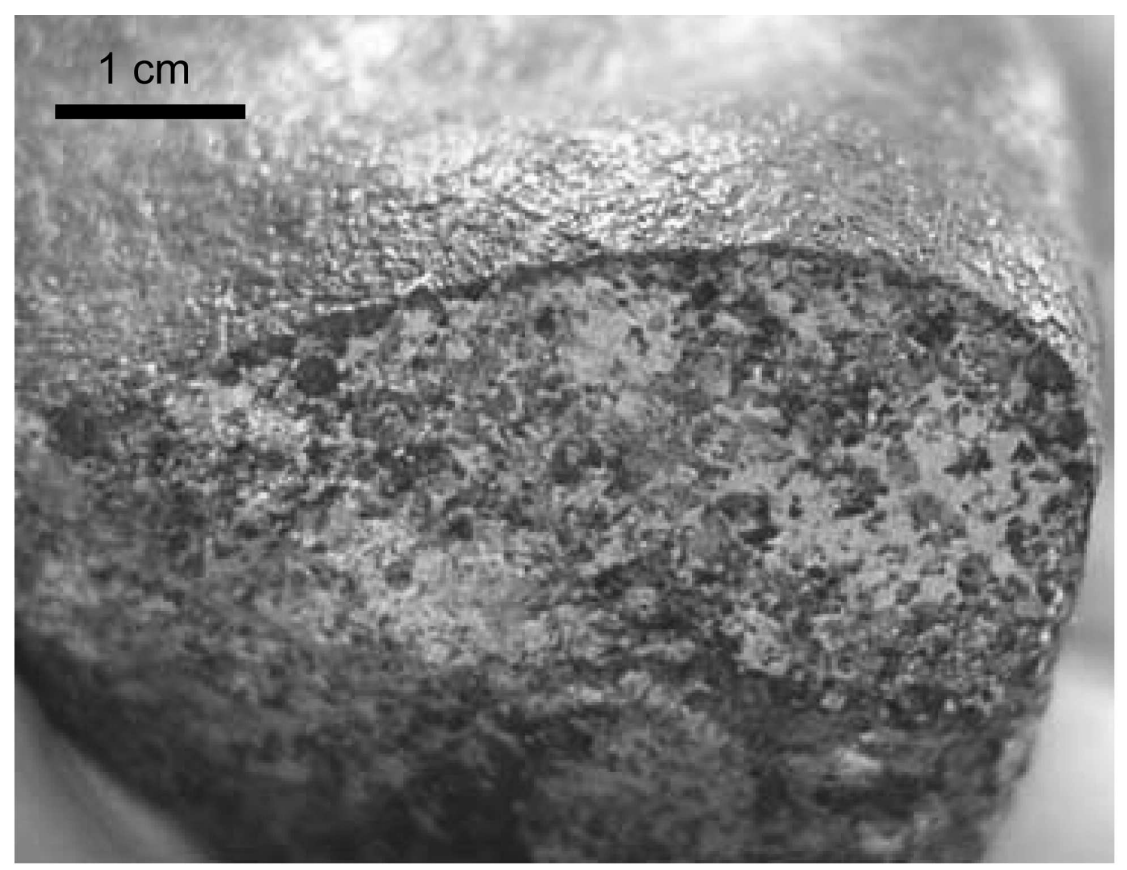

Fig 1. Photograph of a fresh sawn surface of one of the two NWA 1950 stones. As already observed on the other lherzolitic shergottites, NWA 1950 has distinct interpenetrating light and dark greenish regions. The lighter regions are composed of large pyroxenes, while the darker, interstitial regions contain pyroxenes, olivines, maskelynite, accessory minerals, and small amounts of residual mesostasis. (Image courtesy of Carine and Bruno Fectay)

located at the research center of IFREMER at Brest. The analyses were performed at an accelerating voltage of $15 \mathrm{kV}$, a probe current of $12 \mathrm{nA}$ and a $1 \mu \mathrm{m}$-sized spot.

We determined major- and trace-element concentrations by inductively coupled plasma-atomic emission spectrometry (ICP-AES, Brest) and inductively coupled plasma-mass spectrometry (ICP-MS, Southampton), respectively, using the procedure described by Cotten et al. (1995) and Barrat et al. (2000). The accuracy on major- and trace-element concentrations is better than $5 \%$ (probably better than 3\% for all the REEs) based on various standard and sample duplicates.

Raman spectra were recorded with a Labram spectrometer equipped with confocal optics and a nitrogencooled CCD detector. We used a microscope to focus the excitation laser beam $(514 \mathrm{~nm}$ lines of a spectra physics Ar+ laser) to a $2 \mu \mathrm{m}$ spot and to collect the Raman signal in the backscattered direction (Gillet et al. 2000). Collecting times lasted between 10 to $60 \mathrm{~s}$ under small power ( 2 to $30 \mathrm{~mW}$ ), to avoid sample deterioration.

Details of the oxygen 3-isotope analyses are given in Miller et al (1999). Briefly, 1-2 mg aliquots of powdered sample were heated with a $\mathrm{CO}_{2}$ laser $(10.6 \mathrm{~mm})$ in the presence of $\mathrm{BrF}_{5}$ to quantitatively liberate the oxygen gas. Following purification, the gas generated was analyzed on a PRISM III (VG Micromass, UK) to determine the $\delta^{17} \mathrm{O}$ and $\delta^{18} \mathrm{O}$ values. Analytical precision is typically $\pm 0.08 \%$ o for $\delta^{18} \mathrm{O}$ and $\pm 0.024 \%$ for $\Delta^{17} \mathrm{O}$.

\section{NWA 1950: A NEW MARTIAN METEORITE}

NWA 1950 can be undoubtedly included in the Martian meteorite group. Many diagrams or element ratios have been used to discriminate the various types of basaltic achondrites (e.g., Treiman et al. 2000). Key element ratios such as $\mathrm{Fe}^{*} /$ $\mathrm{Mn}(\approx 47), \mathrm{Na} / \mathrm{Al}(\approx 0.28)$, or $\mathrm{Ga} / \mathrm{Al}\left(=4.4 \times 10^{-4}\right)$ indicate that NWA 1950 is a new member of the Martian meteorites clan. This conclusion is confirmed by the bulk rock analysis for oxygen isotopes, which yields $\delta^{17} \mathrm{O}=2.54 \%, \delta^{18} \mathrm{O} \%=$ $4.28 \%$ and $\Delta \Delta^{17} \mathrm{O}=0.312 \%$. These values lie on the Martian mass fractionation line defined by the SNC meteorites (Franchi et al. 1999), with a $\delta^{18} \mathrm{O}$ indistinguishable from the other lherzolitic shergottites (Clayton and Mayeda 1996; Franchi et al. 1999).

\section{PETROGRAPHY AND MINERAL CHEMISTRY}

As already observed on the other lherzolitic shergottites, freshly sawn surfaces of NWA 1950 show distinct interpenetrating light and dark greenish regions (Fig. 1). The meteorite is a plagioclase-bearing ultramafic rock consisting of olivine $(\sim 55 \mathrm{vol} \%)$, low and high-Ca pyroxenes $(\sim 35 \mathrm{vol} \%)$, and maskelynitized plagioclase ( $\sim 8 \mathrm{vol} \%)$. Accessory minerals include phosphates (merrillite), chromite and spinels (inclusions in olivines and pyroxenes), sulfides (pyrothite), and a glass rich in potassium (Fig. 2). The igneous texture is very similar to that of the other known lherzolitic 
Table 1. Electron microprobe analysis of minerals in NWA 1950. Values are in $\mathrm{wt} \%$.

\begin{tabular}{|c|c|c|c|c|c|c|c|c|c|c|c|c|c|c|}
\hline & $\mathrm{SiO}_{2}$ & $\mathrm{TiO}_{2}$ & $\mathrm{Al}_{2} \mathrm{O}_{3}$ & $\mathrm{Cr}_{2} \mathrm{O}_{3}$ & $\mathrm{FeO}$ & $\mathrm{MnO}$ & $\mathrm{MgO}$ & $\mathrm{CaO}$ & $\mathrm{Na}_{2} \mathrm{O}$ & $\mathrm{K}_{2} \mathrm{O}$ & $\mathrm{P}_{2} \mathrm{O}_{5}$ & $\mathrm{NiO}$ & Total & End-members \\
\hline \multicolumn{15}{|l|}{ Olivine } \\
\hline A & 38.42 & 0.00 & 0.01 & 0.84 & 22.42 & 0.56 & 37.86 & 0.10 & 0.01 & 0.00 & 0.02 & 0.16 & 100.43 & $\mathrm{Fo}_{75.1}$ \\
\hline B & 37.89 & 0.06 & 0.04 & 0.14 & 26.89 & 0.29 & 34.73 & 0.20 & 0.00 & 0.07 & 0.02 & 0.00 & 100.34 & $\mathrm{Fo}_{69.7}$ \\
\hline $\mathrm{C}$ & 36.88 & 0.00 & 0.03 & 0.18 & 28.81 & 0.58 & 33.71 & 0.20 & 0.02 & 0.00 & 0.00 & 0.09 & 100.51 & $\mathrm{Fo}_{67.6}$ \\
\hline $\mathrm{n}=290$ & 37.53 & 0.02 & 0.02 & 0.08 & 25.83 & 0.53 & 35.47 & 0.23 & 0.01 & 0.01 & 0.06 & & 99.83 & $\mathrm{Fo}_{71.0}$ \\
\hline \multicolumn{15}{|c|}{ Low-Ca pyroxene } \\
\hline A & 55.50 & 0.06 & 0.38 & 0.36 & 13.10 & 0.66 & 29.55 & 1.25 & 0.05 & 0.00 & 0.00 & 0.00 & 100.93 & $\mathrm{En}_{78.2} \mathrm{Wo}_{2.4} \mathrm{Fs}_{19.4}$ \\
\hline B & 52.73 & 0.43 & 1.49 & 0.63 & 16.77 & 0.71 & 21.17 & 6.61 & 0.08 & 0.00 & 0.00 & 0.00 & 100.66 & $\mathrm{En}_{59.9} \mathrm{Wo}_{13.4} \mathrm{Fs}_{26.6}$ \\
\hline $\mathrm{n}=149$ & 54.34 & 0.13 & 0.52 & 0.50 & 14.58 & 0.52 & 25.93 & 2.75 & 0.05 & 0.01 & 0.02 & 0.03 & 99.39 & $\mathrm{En}_{71.9} \mathrm{Wo}_{5.5} \mathrm{Fs}_{22.7}$ \\
\hline \multicolumn{15}{|l|}{ Augite } \\
\hline A & 53.34 & 0.28 & 1.43 & 0.75 & 9.87 & 0.62 & 18.54 & 15.33 & 0.19 & 0.00 & 0.00 & 0.00 & 100.39 & $\mathrm{En}_{52.8} \mathrm{Wo}_{31.4} \mathrm{Fs}_{15.8}$ \\
\hline B & 53.16 & 0.94 & 1.88 & 0.98 & 8.44 & 0.50 & 15.22 & 19.10 & 0.36 & 0.06 & 0.00 & 0.02 & 100.68 & $\mathrm{En}_{45.2} \mathrm{Wo}_{40.8} \mathrm{Fs}_{14.1}$ \\
\hline $\mathrm{n}=21$ & 52.61 & 0.38 & 1.52 & 0.83 & 9.27 & 0.44 & 17.21 & 16.79 & 0.22 & 0.01 & 0.01 & 0.04 & 99.32 & $\mathrm{En}_{49.9} \mathrm{Wo}_{35.0} \mathrm{Fs}_{15.1}$ \\
\hline \multicolumn{15}{|l|}{ Maskelynite } \\
\hline A & 54.22 & 0.05 & 27.33 & 0.00 & 0.52 & 0.04 & 0.08 & 11.49 & 4.53 & 0.16 & 0.02 & 0.00 & 98.43 & $\mathrm{Ab}_{41.2} \mathrm{An}_{57.8} \mathrm{Or}_{1.0}$ \\
\hline B & 58.17 & 0.12 & 24.89 & 0.00 & 0.56 & 0.05 & 0.10 & 8.48 & 6.10 & 0.41 & 0.00 & 0.00 & 98.89 & $\mathrm{Ab}_{55.2} \mathrm{An}_{42.4} \mathrm{Or}_{2.4}$ \\
\hline $\mathrm{n}=47$ & 54.91 & 0.10 & 26.42 & 0.04 & 0.79 & 0.04 & 0.58 & 10.44 & 5.04 & 0.22 & 0.07 & 0.01 & 98.67 & $\mathrm{Ab}_{46.0} \mathrm{An}_{52.7} \mathrm{Or}_{1.3}$ \\
\hline \multicolumn{15}{|l|}{ K-rich phase } \\
\hline A & 64.37 & 0.47 & 19.56 & 0.02 & 1.04 & 0.05 & 0.30 & 2.19 & 3.23 & 5.54 & 0.41 & 0.00 & 97.201 & \\
\hline B & 72.45 & 0.48 & 16.20 & 0.02 & 1.47 & 0.02 & 0.18 & 1.08 & 2.96 & 5.23 & 0.24 & 0.00 & 100.43 & \\
\hline $\mathrm{n}=13$ & 68.30 & 0.45 & 18.14 & 0.07 & 0.94 & 0.03 & 0.22 & 1.77 & 3.05 & 4.71 & 0.52 & 0.02 & 98.23 & \\
\hline \multicolumn{15}{|l|}{ Oxides } \\
\hline A & 0.00 & 13.88 & 5.23 & 29.39 & 44.84 & 0.76 & 3.63 & 0.00 & 0.00 & 0.00 & 0.01 & 0.04 & 97.77 & \\
\hline B & 0.00 & 0.76 & 5.07 & 60.77 & 26.14 & 0.49 & 5.29 & 0.01 & 0.00 & 0.01 & 0.00 & 0.05 & 98.61 & \\
\hline Ilmenite $\mathrm{n}=3$ & 0.14 & 52.92 & 0.02 & 1.08 & 40.20 & 0.85 & 4.51 & 0.17 & 0.00 & 0.01 & 0.03 & 0.02 & 99.95 & \\
\hline \multirow[t]{2}{*}{ Merrillite $\mathrm{n}=4$} & 0.05 & 0.03 & 0.00 & 0.04 & 1.00 & 0.08 & 3.41 & 47.14 & 1.76 & 0.02 & 46.94 & 0.01 & 100.55 & \\
\hline & $\mathrm{S}$ & $\mathrm{Si}$ & $\mathrm{Mn}$ & $\mathrm{Fe}$ & $\mathrm{Co}$ & $\mathrm{Ni}$ & $\mathrm{Cu}$ & $\mathrm{Zn}$ & Total & & & & & \\
\hline \multicolumn{15}{|l|}{ Sulfide } \\
\hline A & 37.90 & 0.00 & 0.00 & 60.86 & 0.07 & 0.28 & 0.00 & 0.16 & 99.27 & & & & & \\
\hline B & 35.57 & 0.02 & 0.02 & 44.92 & 0.76 & 15.73 & 0.32 & 0.00 & 97.33 & & & & & \\
\hline $\mathrm{n}=16$ & 36.52 & 0.03 & 0.03 & 55.29 & 0.18 & 4.60 & 1.25 & 0.04 & 97.93 & & & & & \\
\hline
\end{tabular}



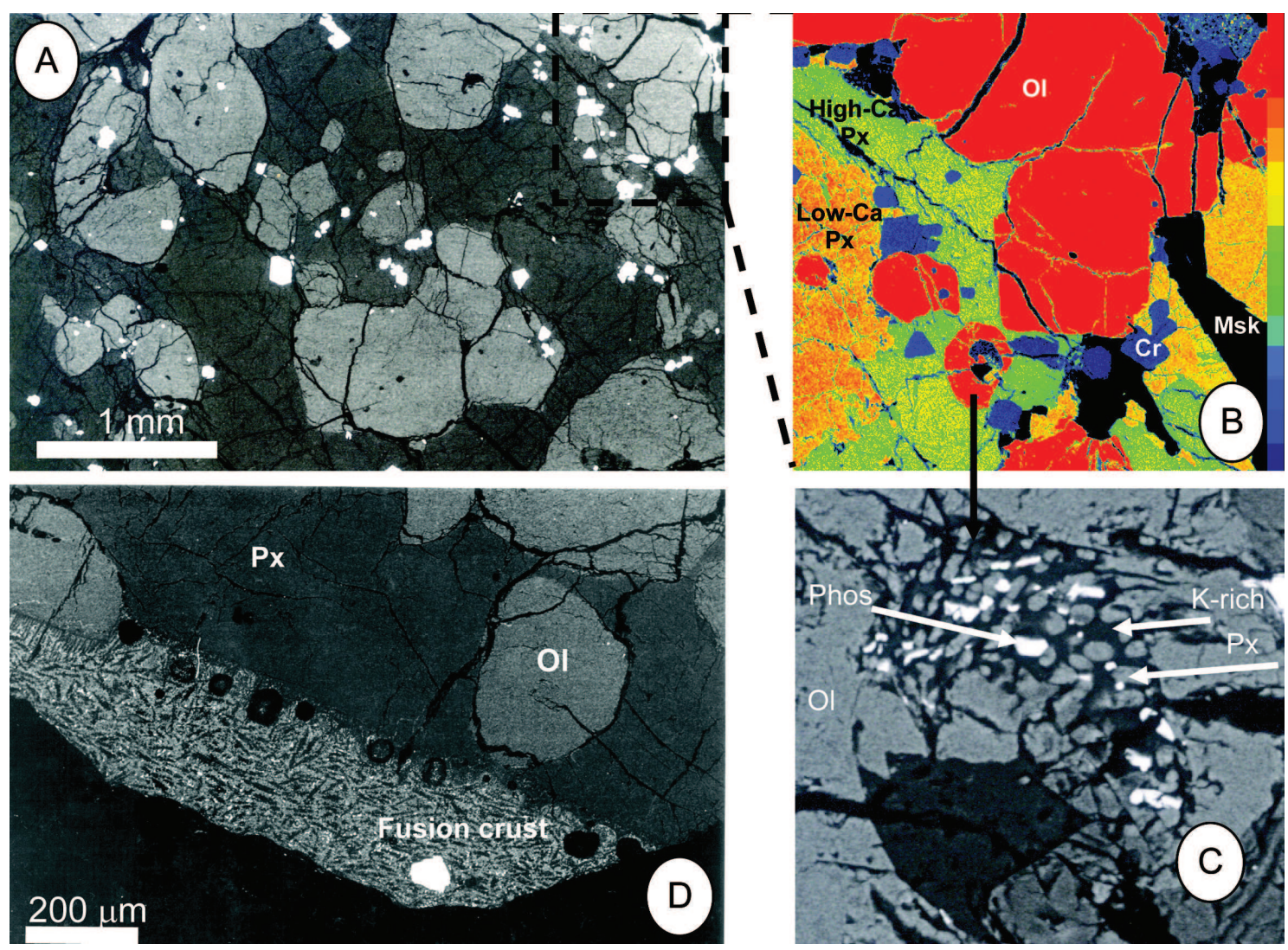

Fig 2. Backscattered electron images of a polished section of NWA 1950. a) A general view of the texture of the rock: light grey: olivine; dark grey: pyroxenes; white: chromites. b) A detailed map of the $\mathrm{Mg}$ content of the different minerals: red: olivine (Ol); green: high-Ca pyroxene; orange: low-Ca pyroxene; black: maskelynite (Msk); blue: chromites $(\mathrm{Cr})$. c) A detailed view of a small zone with interstitial residual melt: K-rich phase (K-rich), pyroxene (Px), phosphate (Phos), maskelynite (Msk). d) A view of the fusion crust showing small, needle-shaped, recrystallized minerals.

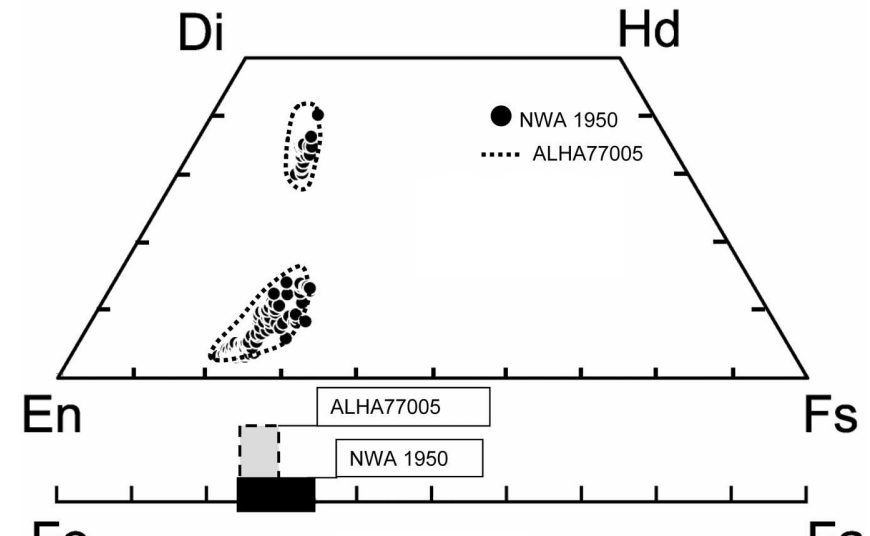

Fo $\mathrm{Fa}$

Fig 3. Composition diagram for pyroxene and olivine in NWA 1950 (full circles). The range of values for the ALH 77005 meteorite are also shown for comparison (McSween et al. 1979; Treiman et al. 1994).

shergottites. NWA 1950 displays poikilitic and non-poikilitic areas. In poikilitic areas, large (up to $6 \mathrm{~mm}$ ) low-Ca pyroxene crystals are observed, and they contain large euhedral olivines and chromites. In the non-poikilitic regions, associations of augitic-pyroxenes (enclosing euhedral olivine), pigeonite, maskelynite are found as well as numerous accessory minerals including chromite, ilmenite, sulfides, phosphates, and K-rich interstitial phase (Fig. 2). Based on textural observations, the following crystallization sequence can be inferred: chromite, olivine, pyroxenes + plagioclase + interstitial phases (phosphate, sulfide, ilmenite, K-rich phase).

\section{Olivine}

The chemical composition of olivine is homogeneous within each grain, but varies from grain to grain and covers the range $\mathrm{Fo}_{66}$ to $\mathrm{Fo}_{75}$ (Table 1 and Fig. 3). No magmatic inclusions were observed in the studied section. Many grains are anhedral. The $\mathrm{FeO} * \mathrm{MnO}$ ratio is $50.53 \pm 10.21$ and lies on the typical trend defined by the SNC olivines (Karner et al. 2003).

\section{Pyroxenes}

Low-Ca pyroxenes have composition varying between $\mathrm{En}_{78} \mathrm{Fs}_{19} \mathrm{Wo}_{2}$ and $\mathrm{En}_{60} \mathrm{Fs}_{26} \mathrm{~W}_{14}$. They show chemical zoning 


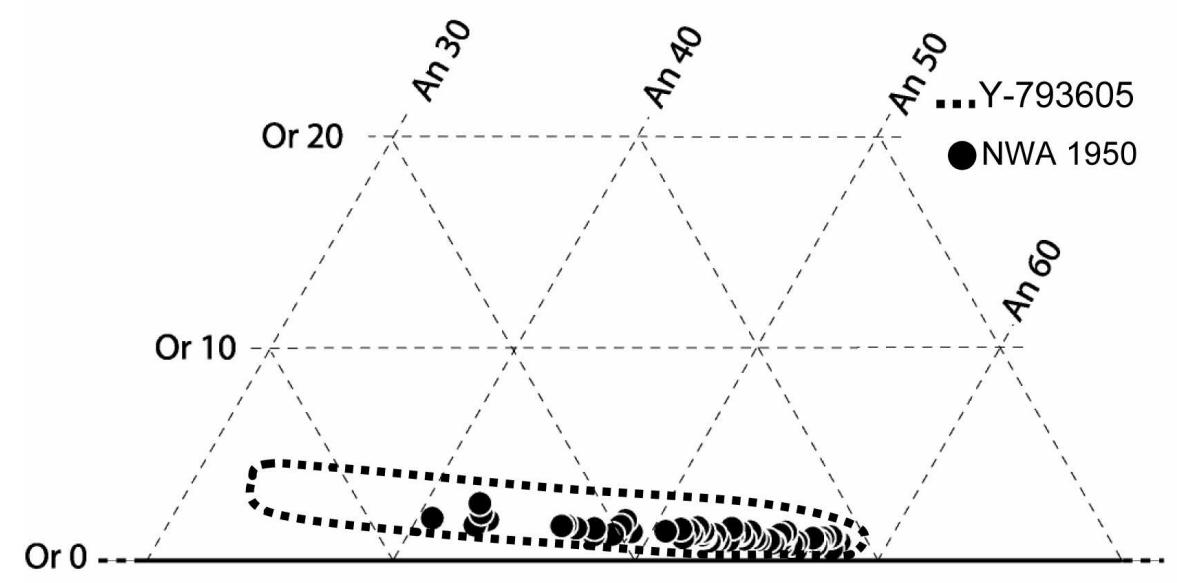

Fig 4. Compositional range of the maskelynite in NWA 1950 (full circles). For comparison, the range of values for the Y-793605 meteorite is shown (Ikeda 1997).

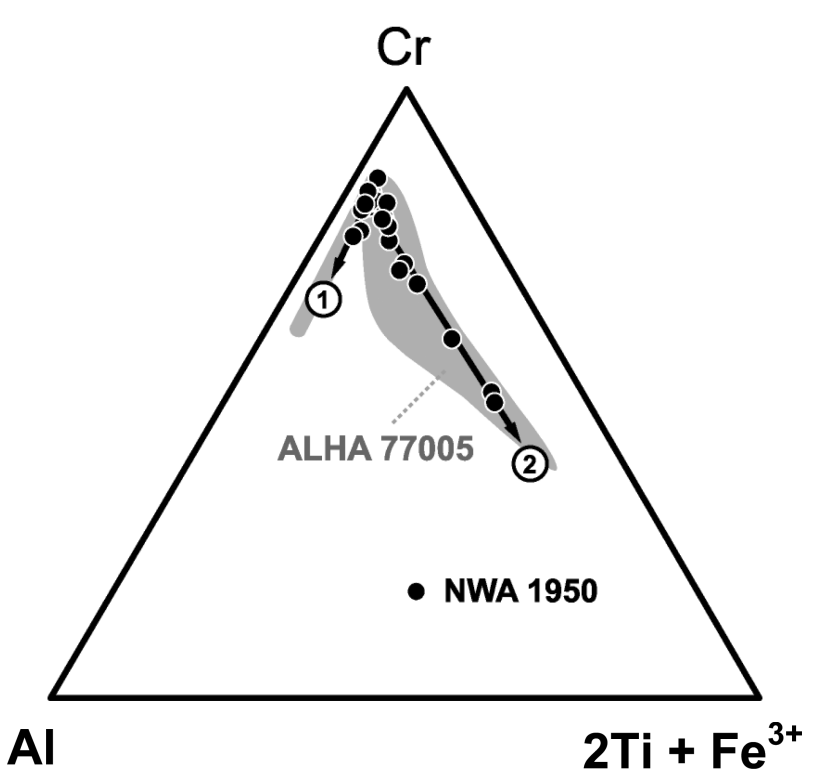

Fig 5. Cr-Al-2Ti $+\mathrm{Fe}^{3+}$ plot (atomic\%) of chromite in NWA 1950. See text for details.

from high-mg and low-Ca cores to mg-rich pigeonite (Table 1 and Fig. 3). The $\mathrm{FeO} * \mathrm{MnO}$ ratio is $29.6 \pm 6.8$. High-Ca pyroxenes observed in both poikilitic and non-poikilitic areas are zoned with chemical compositions ranging from subcalcic augite to Ca-rich augite $\left(\mathrm{En}_{53} \mathrm{Fs}_{16} \mathrm{Wo}_{31}-\mathrm{En}_{45} \mathrm{Fs}_{14} \mathrm{Wo}_{41}\right.$, respectively) (Table 1 and Fig. 3). Augite is in contact with pigeonite indicating co-crystallization. The $\mathrm{FeO} * \mathrm{MnO}$ ratio is $28.2 \pm 6.7$, which is in agreement with pyroxenes observed in other Martian meteorites (Papike 1996; Papike et al. 2003).

\section{Maskelynite}

Former plagioclases are present as pseudomorphs and have been entirely transformed into maskelynite during shock as demonstrated by their Raman spectra characteristics of a plagioclase glass (Table 1 and Fig. 4). They are normally zoned with compositions ranging from $\mathrm{An}_{57} \mathrm{Ab}_{41} \mathrm{Or}_{1}$ to $\mathrm{An}_{40} \mathrm{Ab}_{57} \mathrm{Or}_{3}$. Their mean $\mathrm{FeO}$ content is $0.4 \mathrm{wt} \%$ and can locally reach $0.95 \mathrm{wt} \%$.

\section{Spinels}

Chromites with sizes ranging between 20 and $100 \mu \mathrm{m}$ are present as euhedral grains in olivines and pyroxenes, and are also observed as interstitial grains. They are strongly zoned and their compositions vary from $\mathrm{Cr}$-rich cores to $\mathrm{Fe} / \mathrm{Al} / \mathrm{Ti}$ rich rims as already reported in the other lherzolitic shergottites (Goodrich et al. 2003) (Table 1 and Fig. 5). Two chemical trends are present. Trend 1 corresponds to a nearly pure $\mathrm{Cr}-\mathrm{Al}$ variation (from $\mathrm{Cr}_{87} \mathrm{Sp}_{10} \mathrm{Uv}_{3}$ to $\mathrm{Cr}_{77} \mathrm{Sp}_{19} \mathrm{Uv}_{4}$ ), as expected for the evolution of chromite for a fractional crystallization in a closed system. The second trend is characterized by a continuous increase in the ulvöspinel content (from $\mathrm{Cr}_{87} \mathrm{Sp}_{10} \mathrm{Uv}_{3}$ to $\mathrm{Cr}_{49} \mathrm{Sp}_{13} \mathrm{Uv}_{38}$ ). The absence of the expected stability gap between chromite and ulvöspinel observed in NWA 1950 may reflect a post-crystallization reequilibration by diffusion as already proposed in the case of ALH A77005 (Goodrich et al. 2003).

\section{Other Accessory Phases}

Pyrrhotite is the dominant sulfide. The high Ni-content (up to $16 \%$ ) of the crystals is related to the exsolution of pentlandite (Table 1). Zones enriched in $\mathrm{Cu}$ (up to $11 \%$ ) are also observed within the sulfides.

A K-rich phase has been observed as an interstitial phase between olivine and augite. The composition is clearly nonfeldspathic (Table 1). It could correspond to the K- and Narich glass reported in Y-793605 by Ikeda (Ikeda 1997). The interstitial occurrence of this phase suggests a late residual origin.

Phosphates are rare, often small, and frequently 


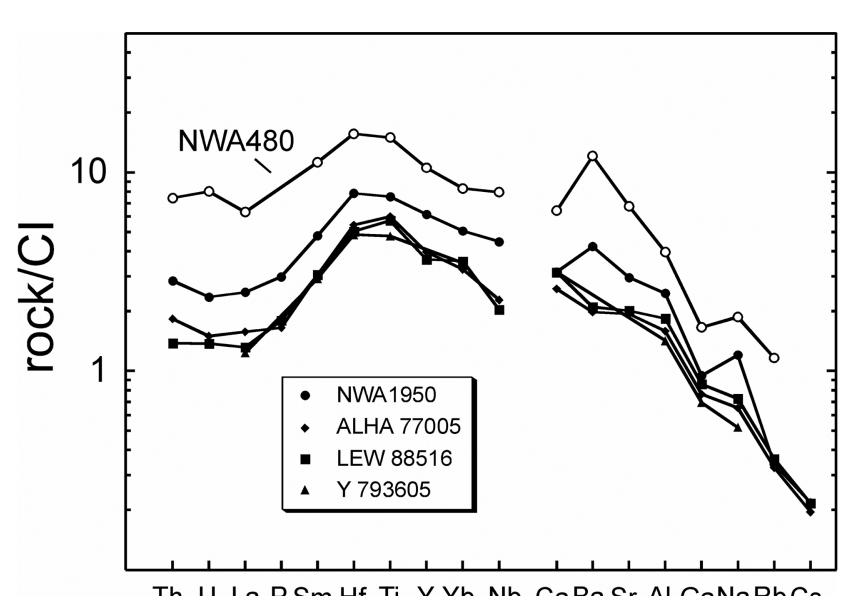

Fig 6. Bulk CI-normalized element contents of NWA 1950 compared to other lherzolitic shergottites and NWA 480, a basaltic shergottite. Data are from Dreibus et al. (1992) for LEW 88516 and ALH A77005, from Warren et al. (1999) for Y-793605, and from Barrat et al. (2002) for NWA 480.

associated with the K-rich phase in the interstices. They correspond to a merrillite poor in $\mathrm{F}$ and $\mathrm{Cl}$ (Table 1). One apatite grain has been identified in the studied section by Raman spectroscopy (Table 1).

$\mathrm{FeTiO}_{3}$ ilmenites with $\mathrm{MgO}$ content up to $4.7 \mathrm{wt} \%$ are usually associated with the interstitial K-rich phase (Table 1).

\section{CHEMISTRY}

A $326 \mathrm{mg}$ interior fragment of the main mass of stone 1 was finely ground using a sapphire mortar and pestle, and was used to determine the major- and trace-element abundances. The results, along with the composition of the fusion crust, are given in Table 2. NWA 1950 is an ultramafic rock, which contains only limited amounts of $\mathrm{Al}, \mathrm{Ca}, \mathrm{Na}, \mathrm{K}$. The composition of the fragment is very similar to that of the fusion crust: only $\mathrm{Cr}_{2} \mathrm{O}_{3}, \mathrm{CaO}$, and $\mathrm{MgO}$ contents are different, suggesting that the analyzed fusion crust formed from an area containing slightly less chromite and more augite than this fragment. The bulk composition of NWA 1950 is close to those of the other lherzolitic shergottites (Table 2 and Fig. 6). These rocks are notoriously heterogeneous and small samples, such as the fragment we have analyzed, cannot be seen as perfectly representative of the whole meteorite. The higher $\mathrm{Al}_{2} \mathrm{O}_{3}, \mathrm{Na}_{2} \mathrm{O}$ and $\mathrm{P}_{2} \mathrm{O}_{5}$ abundances displayed by our analysis of NWA 1950 in comparison with the published results for LEW 88516, ALH A77005, or Y-793605 (Table 2) should not be overemphasized. They indicate only that our sample contains slightly more maskelynitized plagioclase and phosphate than the allocations of other lherzolitic shergottites analyzed by Dreibus et al. (1992) or Warren et al. (1999). Furthermore, the key element ratios such as $\mathrm{Fe} / \mathrm{Mn}$ (47), $\mathrm{Al} / \mathrm{Ti}$ (6.5), Na/Ti (1.82), Ga/Al $\left(4.4 \times 10^{-4}\right)$ and $\mathrm{Na} / \mathrm{Al}(0.28)$ are typical of
Martian meteorites (McSween 1994; Treiman 2003; Wänke and Dreibus 1988).

Unlike many hot desert finds, NWA 1950 has not been severely weathered during its exposure at the Earth's surface. The only trace of terrestrial weathering consists of calcite filling small fractures that run through the sample. The chemical composition of NWA 1950 lacks the well-known chemical fingerprints of Saharan alteration: it has a chondritic $\mathrm{Th} / \mathrm{U}$ ratio (=4.36) and lacks positive Ce-anomaly $\left(\mathrm{Ce} / \mathrm{Ce}^{*}=\right.$ 0.97) or spurious light-REE (LREE) enrichments as observed in the weathered shergottites Dhofar 019 and Dar al Gani $(\mathrm{DaG}) 476$, the Tatahouine diogenite, or the NWA 047 eucrite (Barrat et al. 2001; Barrat et al. 1999; Barrat et al. 2003). Furthermore, weathered hot desert finds often display strong enrichments in $\mathrm{Pb}, \mathrm{Sr}$, and $\mathrm{Ba}$, which are sensitive indicators of terrestrial alteration (e.g., Barrat et al. 2003; Crozaz et al. 2003 and references therein). This is not observed in NWA 1950: this meteorite contains only $84 \mathrm{ng} / \mathrm{g}$ of $\mathrm{Pb}$; the $\mathrm{Sr} / \mathrm{Nd}$ or $\mathrm{Ba} / \mathrm{Sm}$ ratios are similar to the values measured by other teams on various aliquots of the other lherzolitic shergottites found in Antarctica [e.g., Dreibus et al. 1992; Warren et al. 1999]).

Similar to other lherzolitic shergottites (Table 2), NWA 1950 is rich in compatible elements $(\mathrm{Ni}, \mathrm{Cr}, \mathrm{Co})$. Furthermore, despite elevated abundances of $\mathrm{P}$, LREE, and other lithophile elements (such as $\mathrm{Zr}, \mathrm{Nb}, \mathrm{Hf}, \mathrm{Ta}, \mathrm{Th}, \mathrm{U}$ ), which indicate a higher proportion of intercumulus phases (in particular, plagioclase and phosphates) in NWA 1950, the resemblances between NWA 1950 and the other lherzolitic shergottites are obvious, as shown by their REE patterns (Fig. 6).

The strong compositional similarity between NWA 1950 and the other lherzolitic shergottites is impressive and suggests that they were derived from the same magmatic system, or at least that they crystallized from the same kind of parental melt. The determination of the composition of the magmas in equilibrium with cumulates is a difficult task, but in the case of lherzolitic shergottites, the melt fraction trapped between the cumulative olivines clearly governs the incompatible element abundances of the system. Indeed, the incompatible trace-element patterns of the bulk rocks are certainly very similar to those of their parental melts. It can be pointed out that the trace-element patterns of the lherzolitic shergottites and the basaltic shergottite NWA 480/1460 are parallel (Fig. 7). Because NWA 1460 is significantly older than all already dated lherzolitic shergottites (the $\mathrm{Rb} / \mathrm{Sr}$ age is $312 \mathrm{Ma} \pm 3$ for NWA 1460 , while it is about 180 Ma for lherzolitic shergottites; e.g., Borg et al. 2003; Nyquist et al. 2004), these rocks are definitely not directly linked. At the very most, it can be proposed that the resemblances between NWA 480/1460 and the lherzolitic shergottites indicate that they shared very similar parental melts.

The occurrence in NWA 1950 of co-crystallizing spinelolivine-pyroxene assemblages enables the use of the oxybarometer developed by Wood et al. (1991) for spinel 
Table 2. Major and trace element abundances in NWA 1950 compared to three other lherzolitic shergottites.

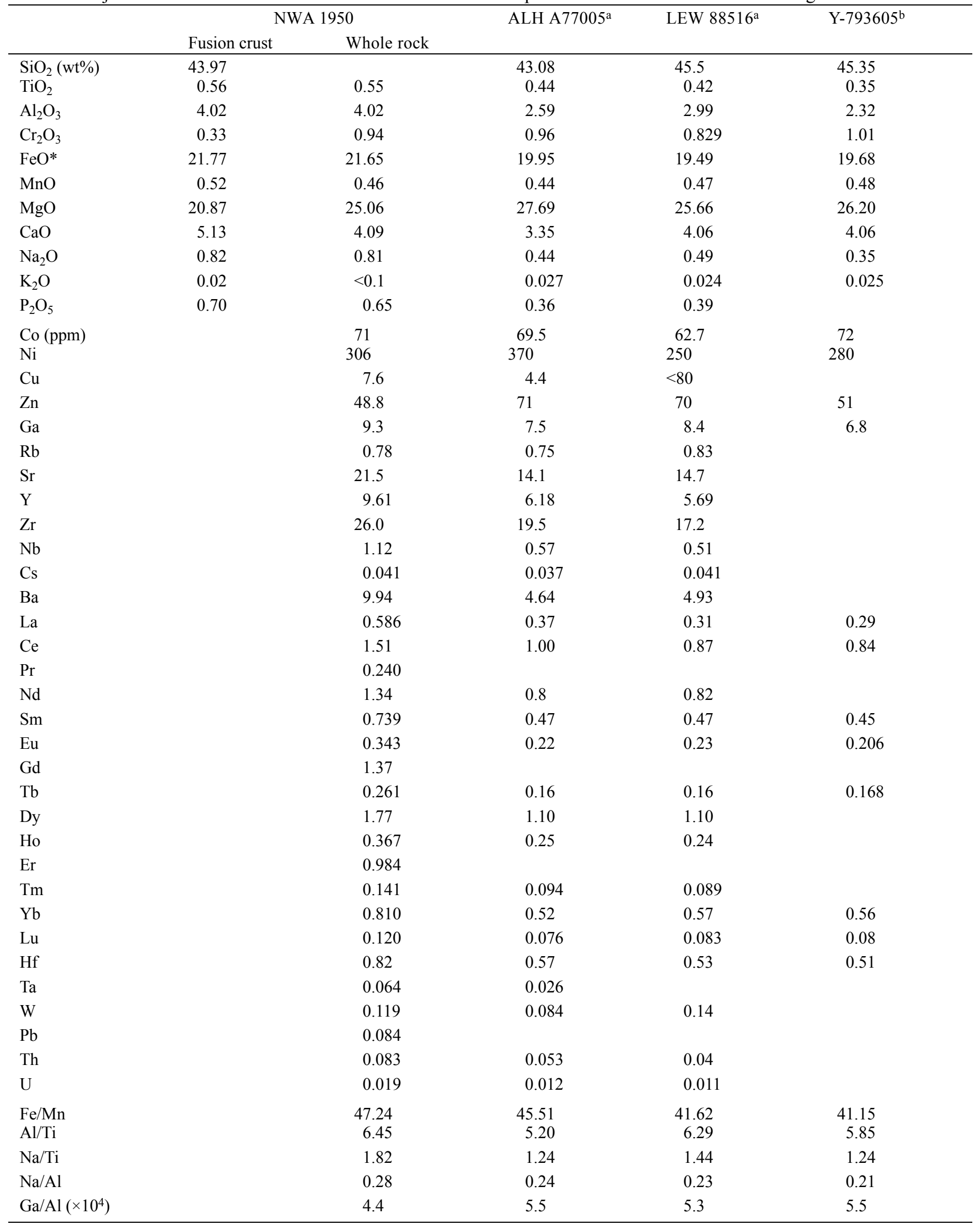

${ }^{\mathrm{a} D}$ Dreibus et al. (1992).

${ }^{\mathrm{b}}$ Warren et al. (1999). 
Table 3. Rare gas isotopic data used for the determination of the cosmic-ray exposure ages of NWA 1950 (see text for details of the method). The sample's mass was $2.38 \mathrm{mg}$.

\begin{tabular}{|c|c|c|c|c|c|}
\hline $\begin{array}{l}{ }^{4} \mathrm{He}(\mathrm{mol} / \mathrm{g}) \\
1.14 \quad 10^{-11} \pm 3.0 \quad 10^{-12}\end{array}$ & $\begin{array}{l}{ }^{3} \mathrm{He} /{ }^{4} \mathrm{He} \\
0.336 \pm 0.195\end{array}$ & $\begin{array}{l}{ }^{3} \mathrm{He}_{\mathrm{c}} \\
3.8210^{-12}\end{array}$ & & & $\begin{array}{l}\mathrm{T}_{3 \mathrm{He}}(\mathrm{Ma}) \\
5.3 \pm 3.0\end{array}$ \\
\hline $\begin{array}{l}{ }^{20} \mathrm{Ne}(\mathrm{mol} / \mathrm{g}) \\
4.6410^{-13} \pm 1.8810^{-14}\end{array}$ & $\begin{array}{l}{ }^{20} \mathrm{Ne} /{ }^{22} \mathrm{Ne} \\
1.01 \pm 0.05\end{array}$ & $\begin{array}{l}{ }^{21} \mathrm{Ne} / 22 \mathrm{Ne} \\
0.708 \pm 0.033\end{array}$ & $\begin{array}{l}{ }^{21} \mathrm{Ne}_{\mathrm{c}} \\
3.2610^{-13}\end{array}$ & $\begin{array}{l}\left({ }^{22} \mathrm{Ne} / 21 \mathrm{Ne}\right)_{\mathrm{c}} \\
138 \pm 3.5\end{array}$ & $\begin{array}{l}\mathrm{T}_{21 \mathrm{Ne}}(\mathrm{Ma}) \\
3.5 \pm 0.8\end{array}$ \\
\hline $\begin{array}{l}36 \mathrm{Ar}(\mathrm{mol} / \mathrm{g}) \\
7.4910^{-14} \pm 2.3410^{-15}\end{array}$ & $\begin{array}{l}{ }^{40} \mathrm{Ar} /{ }^{36} \mathrm{Ar} \\
591 \pm 18\end{array}$ & $\begin{array}{l}38 \mathrm{Ar} / 36 \mathrm{Ar} \\
0.715 \pm 0.028\end{array}$ & $\begin{array}{l}{ }^{38} \mathrm{Ar}_{\mathrm{c}} \\
4.4710^{-14}\end{array}$ & & $\begin{array}{l}\mathrm{T}_{38 \mathrm{Ar}}(\mathrm{Ma}) \\
2.3 \pm 1.0\end{array}$ \\
\hline
\end{tabular}

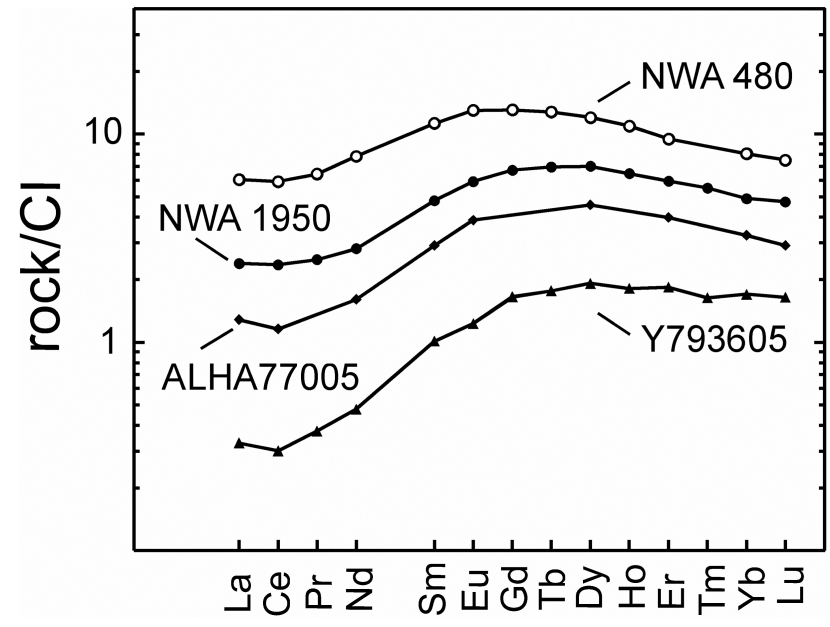

Fig 7. Bulk REE pattern of NWA 1950 compared to those of LEW 88516, ALH A77005 (Shih et al. 1982), Y-793605 (Warren et al. 1999), and NWA 480 (Barrat et al. 2002). The reference chondrite is from Evensen (1978).

peridotite. The temperature of the olivine-spinel equilibration was estimated with the thermometer developed by Sack and Ghiorso (1991a) and the activity of magnetite in chromite was determined with the MELTS supplemental code (Sack and Ghiorso 1991a, 1991b). The calculated oxygen fugacity for NWA 1950 is $-3.5 \pm 0.5$, a result that is within the range for Martian meteorites (Herd et al. 2002). This value is one order of magnitude below the value estimated for other lherzolitic shergottites, ALH A77005 (QFM -2.6 \pm 0.5 , Goodrich et al. $2003)$, but the uncertainty is high $( \pm 0.5)$.

\section{COSMOGENIC AGES}

For the determination of cosmic-ray exposure (CRE) ages, a bulk rock aliquot of $2.38 \mathrm{mg}$ was degassed overnight at $120{ }^{\circ} \mathrm{C}$ under high vacuum and melted with a defocused $\mathrm{CO}_{2}$ laser in a single step. Helium, neon, and argon abundances and isotopic compositions were analyzed by static mass spectrometry (Table 3 ). The analytical details are given in Mathew et al. (2003). During the course of these analyses, the mass spectrometer source settings were adapted to the analysis of heavy noble gases, resulting in the loss of sensitivity for helium and, consequently, large analytical uncertainty on its isotopic ratio (Table 3). For the identification of trapped and cosmogenic $\mathrm{Ne}$, the following

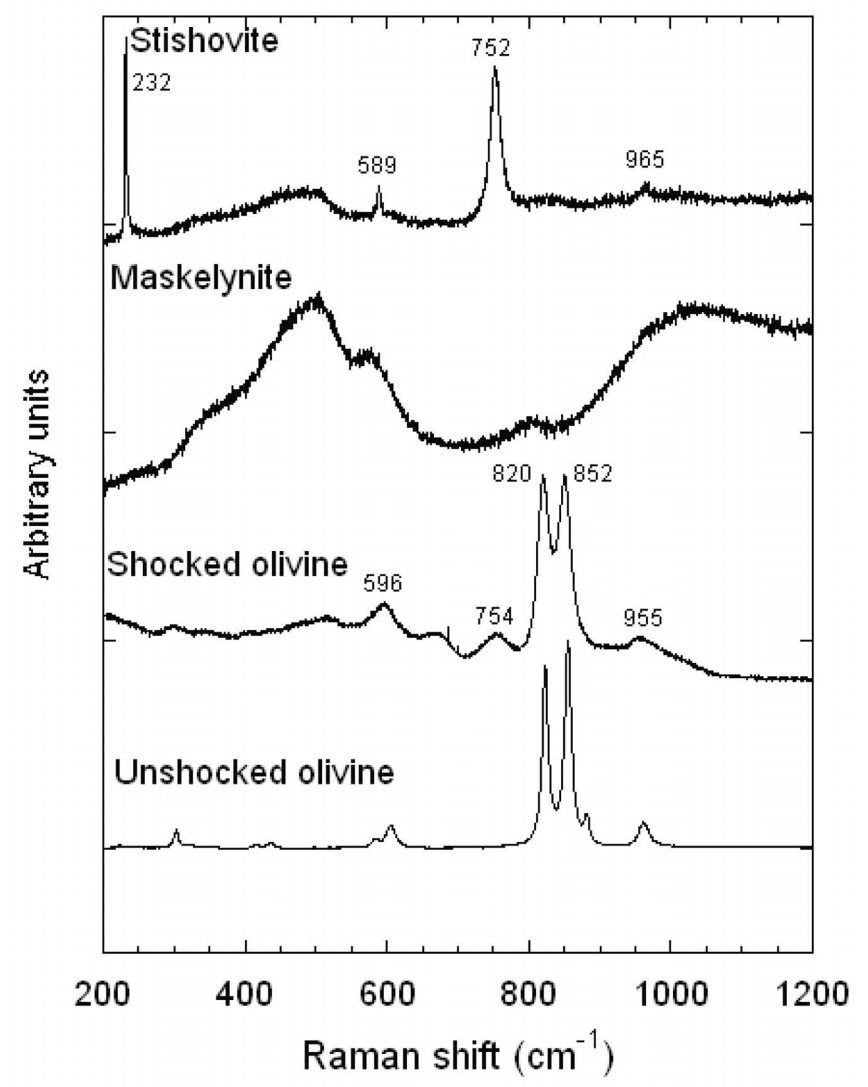

Fig 8. Raman spectra of phases typical of the shock-induced transformations in NWA 1950: spectrum of a stishovite aggregate located in a melt pocket; spectrum of a maskelynite; spectrum of a heavily deformed olivine showing broad bands and an additional peak near $750 \mathrm{~cm}^{-1}$ suggesting the presence of Si-O-Si bridges characteristic of wadsleyite. Reference spectrum of an undeformed olivine from San Carlos.

values were adopted: $\left({ }^{20} \mathrm{Ne} /{ }^{22} \mathrm{Ne}\right)_{\mathrm{t}}=10.6,\left({ }^{21} \mathrm{Ne} / 22 \mathrm{Ne}\right)_{\mathrm{t}}=0.03$, and $\left({ }^{0} \mathrm{Ne} /{ }^{22} \mathrm{Ne}\right)_{\mathrm{c}}=0.80,\left({ }^{21} \mathrm{Ne} /{ }^{22} \mathrm{Ne}\right)_{\mathrm{c}}=0.71$. The choice of the trapped component values has little bearing on computed ages since the data are very close to the cosmogenic end-member $\left({ }^{20} \mathrm{Ne} /{ }^{22} \mathrm{Ne}\right)_{\text {sample }}=1.01 \pm 0.05,\left({ }^{21} \mathrm{Ne} /{ }^{22} \mathrm{Ne}\right)_{\text {sample }}=0.708 \pm$ $0.033) .{ }^{3} \mathrm{He}$ was assumed to be entirely cosmogenic since observed ${ }^{3} \mathrm{He} /{ }^{4} \mathrm{He}$ ratios are two orders of magnitude higher than the solar value.

The very high $\left({ }^{22} \mathrm{Ne} /{ }^{21} \mathrm{Ne}\right)_{c}$ value of 1.38 suggests NWA 1950 was an insignificantly shielded meteoroid, and may indicate some contribution by solar cosmic rays (SCR) in 
addition to galactic cosmic rays (GCR) spallation component. The cosmogenic production rates of ${ }^{3} \mathrm{He},{ }^{21} \mathrm{Ne}$, and ${ }^{38} \mathrm{Ar}$ were calculated following the method of Eugster and Michel (1995). The method computes production rates for moderate shielding depth and apply to the result a moderation factor computed using the $\left({ }^{22} \mathrm{Ne} /{ }^{21} \mathrm{Ne}\right)_{\mathrm{c}}$ value. Eugster and Michel (1995) did not specify a moderation for ${ }^{38} \mathrm{Ar}$ production in achondrites, arguing that the dependency of ${ }^{38} \mathrm{Ar}$ production is negligible, which is in contrast to the conclusions of Cressy and Michel (1976) and Eugster (1988), who proposed essentially similar shielding corrections. Since the $\left({ }^{22} \mathrm{Ne} /\right.$ $\left.{ }^{21} \mathrm{Ne}\right)_{\mathrm{c}}$ value of the present sample is high, we corrected the ${ }^{38} \mathrm{Ar}$ production for shielding using the correction equation given by Eugster (1988).

The calculated CRE ages as obtained by various chronometers (Table 3) spread over a significant time interval; $2.3 \pm 1.0 \mathrm{Ma}$ for ${ }^{38} \mathrm{Ar}_{\mathrm{c}}, 3.5 \pm 0.8 \mathrm{Ma}$ for ${ }^{21} \mathrm{Ne}_{\mathrm{c}}$, and $5.3 \pm 3.0 \mathrm{Ma}$ for ${ }^{3} \mathrm{He}_{\mathrm{c}}$. These CRE ages cover in fact those reported for other lherzolitic shergottites (2.5-3.4 Ma for ALH 77005, 3.0-4.1 Ma for LEW 88516, 3.9-5.4 Ma for Y7936605, with two different CRE noble gas ages reported for the latter in the same study (see Meyer [2004] and references therein). The reason for such a spread is unclear and, in the case of NWA 1950, could be the result of its high $\left({ }^{22} \mathrm{Ne} /{ }^{21} \mathrm{Ne}\right)_{\mathrm{c}}$ value leading to drastic adjustments in the correction procedure, or to a complex exposure history involving for example SRC. Such a complex exposure history, if real, will necessitate further detailed noble gas studies on separated mineral phases.

\section{SHOCK FEATURES}

NWA 1950 has been extensively shocked. All the plagioclases have been converted to maskelynite, as demonstrated by their Raman spectra (Fig. 8). Olivine and pyroxene crystals are intensively fractured, as observed in the other lherzolitic shergottites. Some olivine crystals display Raman spectra with broadened bands indicating intense lattice distortion (Fig. 8). In some areas, these heavily distorted olivine crystals show an additional Raman band near $750 \mathrm{~cm}^{-1}$ (Fig. 9) suggesting the local formation of Si-O-Si bridges as in $(\mathrm{Mg}, \mathrm{Fe})_{2} \mathrm{SiO}_{4}$-wadsleyite, the high-pressure polymorph of olivine (Gillet et al. 2002). Small shockinduced melt pockets are also present. In some of these, aggregates of $\mathrm{SiO}_{2}$-stishovite embedded in glass have been identified by their Raman spectra (Fig. 8). The presence of stishovite in melt pockets or in association with maskelynite seems to be a characteristic and widespread feature of shock metamorphism in shergottites (Jambon et al. 2002; Beck et al. 2004; El Goresy, Forthcoming).

\section{CONCLUSIONS}

We have performed the most general characterization of the NWA 1950 meteorite. This stone is very similar to other described lherzolitic shergottites from a petrographic point of view. The geochemical characteristics as well as the shock features are also very close to those of the other lherzolitic shergottites, which suggests an origin from the same area of the Martian subsurface.

Acknowledgments-Bruno Fectay and Karine Bidaut are thanked for providing us with a sample of the NWA 1950 meteorite. This research has made use of NASA Astrophysics Data System Abstract Service and the Mars Meteorite Compendium compiled by Charles Meyer. Thanks are due for financial support to the CNRS and INSU.

Editorial Handling-Dr. Allan Treiman

\section{REFERENCES}

Barrat J. A., Blichert-Toft J., Gillet P., and Keller F. 2000. The differentiation of eucrites: The role of in-situ crystallization. Meteoritics \& Planetary Science 35:1087-1100.

Barrat J. A., Blichert-Toft J., Nesbitt R. W., and Keller F. 2001. Bulk chemistry of Saharan shergottite Dar al Gani 476. Meteoritics \& Planetary Science 36:23-29.

Barrat J. A., Gillet P., Lesourd M., Blichert-Toft J., and Poupeau G. R. 1999. The Tatahouine diogenite: Mineralogical and chemical effects of 63 years of terrestrial residence. Meteoritics \& Planetary Science 34:91-97.

Barrat J. A., Gillet P., Sautter V., Jambon A., Javoy M., Göpel C., Lesourd M., Keller F., and Petit E. 2002. Petrology and geochemistry of the basaltic shergottite Northwest Africa 480. Meteoritics \& Planetary Science 37:487-499.

Barrat J. A., Jambon A., Bohn M., Blichert-Toft J., Sautter V., Göpel C., Gillet P., Boudouma O., and Keller F. 2003. Geochemistry of the unbrecciated achondrite Northwest Africa 1240 (NWA 1240): An HED parent body impact melt. Geochimica et Cosmochimica Acta 67:3959-3970.

Borg L. E., Nyquist L. E., Wiesmann H., and Reese Y. 2002. Constraints on the petrogenesis of Martian meteorites from the $\mathrm{Rb}-\mathrm{Sr}$ and $\mathrm{Sm}-\mathrm{Nd}$ isotopic systematics of the lherzolitic shergottites ALH 77005 and LEW 88516. Geochimica et Cosmochimica Acta 66:2037-2053.

Beck P., Gillet P., Gautron L., Daniel I., and El Goresy A. 2004. A new natural high-pressure ( $\mathrm{Na}-\mathrm{Ca})$-hexaluminosilicate $\left[\left(\mathrm{Ca}_{\mathrm{x}} \mathrm{Na}_{1-\mathrm{x}}\right) \mathrm{Al}_{3}+\mathrm{xSi}_{3-\mathrm{x}} \mathrm{O}_{11}\right]$ in shocked Martian meteorites. Earth and Planetary Science Letters 219:1-12.

Clayton R. N. and Mayeda T. K. 1996. Oxygen isotopic studies of achondrites. Geochimica et Cosmochimica Acta 60:1999-2017.

Cotten J., Ledez A., Bau M., Caroff M., Maury R. C., Dulski P., Fourcade S., Bohn M., and Brousse R. 1995. Origin of anomalous rare-earth element and yttrium enrichments in subaerially exposed basalts: Evidence from French Polynesia. Chemical Geology 119:115-138.

Cressy P. J. and Bogard D. D. 1976. On the calculation of cosmic-ray exposure ages of stone meteorites. Geochimica et Cosmochimica Acta 40:749-762.

Crozaz G., Floss C., and Wadhwa M. 2003. Chemical alteration and REE mobilization in meteorites from hot and cold deserts. Geochimica et Cosmochimica Acta 67:4727-4741.

Dreibus G., Jochum K. H., Palme H., Spettel B., Wlotzka F., and Wänke H. 1992. LEW 88516: A meteorite compositionally close to the "Martian mantle." Meteoritics 27:216-217.

El Goresy A., Dubrovinsky L., Sharp T. G., and Chen M. 
Forthcoming. Stishovite and post-stishovite polymorphs of silica in the Shergotty meteorite: their nature, petrographic settings versus theoretical predictions and relevance to Earth's mantle. Journal of Physics and Chemistry of Solids.

Eugster O. 1988. Cosmic-ray production rates for ${ }^{3} \mathrm{He},{ }^{21} \mathrm{Ne},{ }^{38} \mathrm{Ar}$, ${ }^{83} \mathrm{Kr}$, and ${ }^{126} \mathrm{Xe}$ in chondrites based on ${ }^{81} \mathrm{Kr}-\mathrm{Kr}$ exposure ages. Geochimica et Cosmochimica Acta 52:1649-1662.

Eugster O. and Michel T. 1995. Common asteroid breakup events of eucrites, diogenites, and howardites and cosmic-ray production rates for noble gases in achondrites. Geochimica et Cosmochimica Acta 59:177-199.

Evensen N. M., Hamilton P. J., and O'Nions R. K. 1978. Rare earth abundances in chondritic meteorites. Geochimica et Cosmochimica Acta 42:1199-1212.

Franchi I. A., Wright I. P., Sexton A. S., and Pillinger C. T. 1999. The oxygen isotopic composition of Earth and Mars. Meteoritics \& Planetary Science 34:657-661.

Gillet P., Chen C., Dubrovinsky L., and Goresi E. 2000. Natural $\mathrm{NaAlSi}_{3} \mathrm{O}_{8}$-hollandite in the shocked Sixiangkou meteorite. Science 287:1633-1636.

Gillet P. 2002. Application of vibrational spectroscopy to geology. In Handbook of vibrational spectroscopy, edited by Chalmers J. M. and Griffiths P. R. Chichester: John Wiley \& Sons. pp. 1-23.

Gleason J. D., Kring D. A., Hill D. H., and Boynton W. V. 1997. Petrography and bulk chemistry of Martian lherzolite LEW 88516. Geochimica et Cosmochimica Acta 18:4007-4014.

Goodrich C. A., Herd C. D. K., and Taylor L. A. 2003. Spinels and oxygen fugacity in olivine-phyric and lherzolitic shergottites. Meteoritics \& Planetary Science 38:1773-1792.

Harvey R. P., Wadhwa M., McSween H. Y., and Crozaz G. 1993. Petrography, mineral chemistry and petrogenesis of Antarctic shergottite LEW 88516. Geochimica et Cosmochimica Acta 57: 4769-4783.

Herd C. D. K., Borg L. E., Jones J. H., and Papike J. J. 2002. Oxygen fugacity and geochemical variations in the martian basalts: Implications for Martian basalt petrogenesis and the oxidation state of the upper mantle of Mars. Geochimica et Cosmochimica Acta 66:2025-2036.

Hsu W., Guan Y., Wang H., Leshin L. A., Wang R., Zhang W., Chen X., Zhang E., and Lin C. 2004. The lherzolitic shergottite Grove Mountains 99027: Rare earth element geochemistry. Meteoritics \& Planetary Science 39:701-709.

Ikeda Y. 1997. Petrology and mineralogy of the Y-793605 Martian meteorite. Antarctic Meteorite Research 10:13-40.

Jambon A., Barrat J. A., Sautter V., Gillet P., Göpel C., Javoy M., Joron J. L., and Lesourd M. 2002. The basaltic shergottite Northwest Africa 856 (NWA 856): Petrology and chemistry. Meteoritics \& Planetary Science 37:1147-1164.

Karner J., Papike J. J., and Shearer C. K. 2003. Olivine from planetary basalts: chemical signatures that indicate planetary parentage and those that record igneous setting and process. American Mineralogist 88:806-816.

Mathew K. J., Marty B., Marti K., and Zimmermann J. L. 2003. Volatiles (nitrogen, noble gases) in recently discovered SNC meteorites, extinct radioactivities, and evolution. Earth and Planetary Science Letters 214:27-42.

McSween H. Y., Jr. 1994. What we have learned about Mars from SNC meteorites. Meteoritics 29:757-779.

McSween H. Y., Jr., Taylor L. A., and Stolper E. 1979. Alan Hills
77005: A new meteorite type found in Antarctica. Science 204: 1201-1203.

Meyer C. 2004. NASA Mars meteorite compendium. http://www. curator.jsc.nasa.gov/curator/antmet $/ \mathrm{mmc} / \mathrm{mmc} . h \mathrm{tm}$.

Mikouchi T. and Miyamoto M. 1996. A new member of lherzolitic shergottite from the Japanese Antarctic meteorite collection: Mineralogy and petrology of Yamato-793605 (abstract). Antarctic Meteorites XXI: 04-106.

Miller M. F., Franchi I. A., Sexton A. S., and Pillinger C. T. 1999. High precision $\delta^{17} \mathrm{O}$ measurements of oxygen from silicates and other oxides: Method and applications. Rapid Communications in Mass Spectrometry 13:1211-1217.

Nyquist L. E., Shih C. Y., Reese Y. D., and Irving A. J. 2004. Crystallization age of NWA 1460 shergottite: Paradox revisited (abstract). Second Conference on Early Mars: Geologic, Hydrologic, and Climatic Evolution and the Implications for Life.

Papike J. J. 1996. Pyroxenes as a recorder of cumulate formational processes in asteroids, Moon, Mars, Earth: Reading the record with ion microprobe. American Mineralogist 81:525-544.

Papike J. J., Karner J. M., and Shearer C. K. 2003. Determination of planetary basalt parentage: A simple technique using the electron microprobe. American Mineralogist 88:469-472.

Romanek C. S., Perry E. C., Treiman A. H., Socki R. A., Jones J. H., and Gibson E. K. 1998. Oxygen isotopic record of silicate alteration in the Shergotty-Nakhla-Chassigny meteorite Lafayette. Meteoritics \& Planetary Science 33:775-784.

Sack R. O. and Ghiorso M. S. 1991a. Chromian spinels as petrogenetic indicators-Thermodynamics and petrological applications. American Mineralogist 76:827-847.

Sack R. O. and Ghiorso M. S. 1991b. An internally consistent model for the thermodynamic properties of $\mathrm{Fe}-\mathrm{Mg}$-titanomagnetitealuminate spinels. Contributions to Mineralogy and Petrology 106:474-505.

Shih C. Y., Nyquist L. E., Bogard D. D., McKay G. A., Wooden J. L., Bansal B. M., and Wiessmann H. 1982. Chronology and petrogenesis of young achondrites, Shergotty, Zagami, and ALH A77005: Late magmatism on a geologically active planet. Geochimica et Cosmochimica Acta 46:2323-2344.

Treiman A. H. 2003. Chemical compositions of martian basalts (shergottites): Some inferences on basalt formation, mantle metasomatism, and differentiation in Mars. Meteoritics \& Planetary Science 38:1849-1864.

Treiman A. H., Gleason J. D., and Bogard D. D. 2000. The SNC meteorites are from Mars. Planetary and Space Science 48: 1213-1320.

Treiman A. H., McKay G. A., Bogard D. D., Mittlefehldt D. W., Wang M. S., Keller L., Lipschutz M. E., Lindstrom M. M., and Garrison D. 1994. Comparison of the LEW 88516 and ALH 77005 Martian meteorites: Similar but distinct. Meteoritics \& Planetary Science 29:581-592.

Wänke H. and Dreibus G. 1988. Chemical composition and accretion history of terrestrial planets. Philosophical Transactions of the Royal Society of London A 325:545-557.

Warren P. H., Kallemeyn G. W., and Kyte F. T. 1999. Origin of planetary cores: Evidence from highly siderophile elements in Martian meteorites. Geochimica et Cosmochimica Acta 63: 2105-2122. 